\title{
Strengthening Institutional Aspects of Farmers, Cipanas, Kabupaten Cianjur
}

\author{
Arjuna Rizaldi ${ }^{*}$ \\ ${ }^{1}$ Indonesian Computer University, Indonesia \\ arjuna@email.unikom.ac.id $\left.{ }^{1^{*}}\right)$
}

\begin{abstract}
Abstrak
Koperasi adalah Lembaga yang dibentuk dengan tujuan menyejahterakan anggota pada khususnya dan masyarakat umumnya. Kegiatan PKM ini dilakukan dengan tujuan untuk menumbuhkan kesadaran petani desa Cipanas Kabupaten Cianjur untuk menggabungkan dirinya dalam sebuah koperasi guna meningkatkan daya saing petani desa Cipanas secara umum. Kegiatan ini dilakukan melalui penyusunan model penguatan kelembagaan petani dan penyuluhan kepada para petani dalam rangka menumbuhkan kesadaran petani untuk ikut begabung dalam membentuk koperasi. Hasil dari kegiatan ini adalah tumbuhnya kesadaran (awareness) petani pentingnya untuk menggabungkan diri ke dalam koperasi sebagai Langkah awal pembentukan koperasi.
\end{abstract}

Kata kunci: koperasi, kelembagaan, petani, daya saing, manajemen

\begin{abstract}
Cooperative is an institution formed with the aim of prospering members in particular and society in general. This PKM activity was carried out with the aim of raising awareness of Cipanas village farmers, Cianjur Regency to join themselves in a cooperative in order to increase the competitiveness of Cipanas village farmers in general. This activity is carried out through the formulation of a model for strengthening farmer institutions and counseling to farmers in order to raise awareness of farmers to join in forming cooperatives. The result of this activity is the growing awareness of farmers about the importance of joining a cooperative as the first step in forming a cooperative.
\end{abstract}

Keywords : cooperative, institutions, farmers, competitiveness, management

\section{Introduction}

Cooperative comes from two words, namely Co and Operation, Co means together and Operation means activity or work. The two words are combined to form Cooperation or cooperative, which means jointly carrying out activities or work to achieve a common goal in a democratic, open and voluntary manner.

Several experts expressed their opinion about the definition of cooperatives. According to Hendrojogi (2007: 21) cooperative is a business entity consisting of people or cooperative legal entities based on their activities based on cooperative principles as well as a people's economic movement based on the principle of kinship. Cooperatives are also autonomous associations of persons united voluntarily to meet the needs of shared economic, social and cultural aspirations through jointly owned and democratically controlled enterprises (ICA, 1995). According to Ropke (1997) defines a cooperative as a business organization whose owners or members are also 

the company's main customers (identity criteria). Furthermore, Ropke (1997) defines cooperatives as business organizations whose owners or members are also the company's main customers (identity criteria). This definition is in line with UndangUndang No. 25 Tahun 1992 tentang Koperasi, Indonesian cooperatives are people's economic organizations with a social character, consisting of people or cooperative law which is an economic arrangement as a joint effort based on the principle of kinship (asas kekeluargaan), in which the members of cooperative are also the owner and customer of cooperative.

Seeing the importance of the role of cooperatives in the welfare of the community, we feel that cooperatives need to be developed massively, judging from the large number of people who are considered to have weak incomes or economic values. We take one real example based on data from the Central Statistics Agency (BPS) of Cianjur Regency claiming that $9.81 \%$ of the population of Cianjur belongs to the poor community or in numbers there are as many as 35,830 people out of a total population of 2,263,072 people. In Cianjur Regency and its surroundings, based on existing data there are 1,503 cooperatives but only 303 cooperatives are active. Seeing this, of course, it is very unfortunate, Cianjur should have been able to improve its economic level from the aspect of institutional development, in fact it has not been able to do this, this is due to the lack of strength of the institution itself in its development and operation. Therefore, it is very necessary to form a strong institution as an example as well as a tool for community empowerment.

In developing and strengthening cooperatives for the Cianjur Regency area, we propose the creation of food cooperatives, as we know that food cooperatives are broadly concerned with the needs of many people's lives and are the 3rd largest contributor to Indonesia's Gross Domestic Product (GDP). The concern here is that the existing food cooperatives are still not optimal, one of the reasons for this is the supply chain that is too complicated and long.

$\mathrm{AH}$. Gophar said that cooperative management can basically be studied from three perspectives, namely organization, process and style (Hendar and Kusnadi; 1999). In developing a cooperative, of course, it cannot directly form a mass, here we are required to focus on building a competent marketing system for a strong institution and of course can shorten the supply chain which is currently considered too complicated and long, the first step we will take do is create in the scope of the area that is not too large and expand it for a wider scope.

Thus, for the community, this activity aims to provide opportunities for community economic development through a strong institution and can be carried out independently by the community itself so that the benefits of an institution will always be obtained by the community, of course with a new system formed so that all activities or mechanisms in it run in a structured manner. which is expected to be the key to the efficiency and effectiveness of community welfare. From an academic point of view, the purpose of this activity is to carry out community service tasks by applying management knowledge.

\section{Implementation Method}

In this activity we focus on farmers in Cipanas Village, Cipanas District, Cianjur Regency. The material given to farmers in Cipanas Village, Cianjur Regency is in the form of counseling about farmer organization networks as the core of strengthening farmer institutions and expanding marketing from this institution which includes:

a. Formation of farmer groups according to the type of plant

b. Formation of cooperatives as a forum for strengthening farmer organizations 
c. Expansion of the online marketing network (online)

d. Expansion of the direct marketing network to end users, which includes:

1) Modern supermarket (Minimarket, Supermarket, Hypermarket)

2) Traditional market

3) Food processing factory

4) Restaurant and Hotel

e. Provision of special operators in the form of telemarketing for sales to hotels

f. Recruitment of group members for supplier gathering

The development model of farmer cooperatives in Cipanas Village, Cianjur Regency involves various parties including:

1) Farmer's Group as initiator

2) Village Government as facilitator

3) Banks and financial institutions as funders

4) Training Institute/University as trainer/cooperative member coach

5) People's markets, traditional markets, and online markets as marketing purposes.

The Cipanas Village farmer cooperative development model can be seen in the following picture

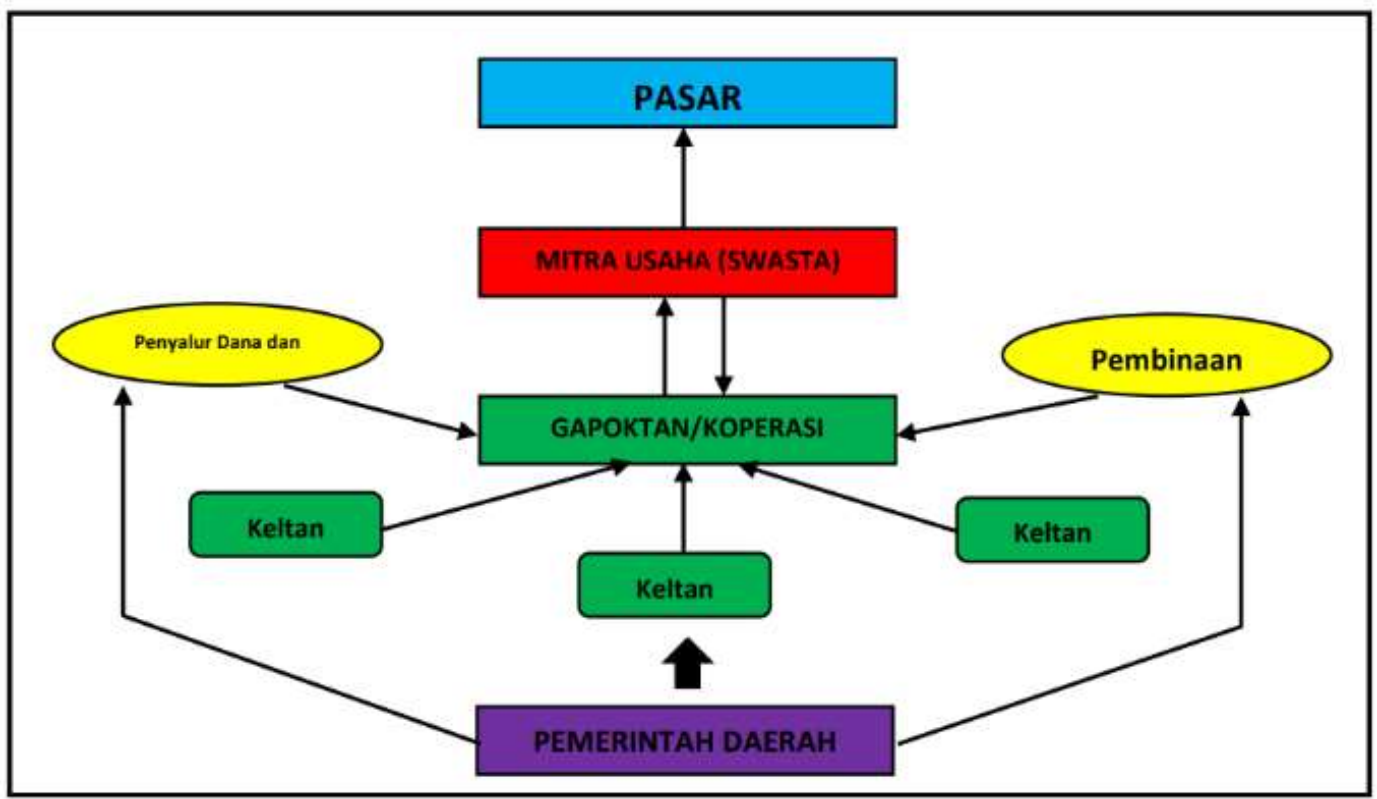

Figure 1. Development Model for Farmers' Cooperatives in Cipanas Village, Cianjur Regency

The implementation method in PKM activities in Cipanas Village, Cianjur Regency is carried out through:

a. Collecting and organizing farmers in Cipanas village, Cianjut . Regency

b. Direct visit to farmers

c. Counseling on the institutions and organization of farmers.

a. Resistance

The obstacles encountered in the implementation of PKM activities in Cipanas Village, Cianjur Regency include:

a. The farmers' interest has not yet grown to join themselves in an official organization, 
b. Do not have the competence to be recruited as administrators as well as members of farmer groups/cooperatives,

c. Very limited initial operating costs,

d. Most members have not maximized the use of technology,

e. There is no growing trust from consumers to use farmers' products.

b. Solution

a. Educating members, especially farmers, about the advantages of the formation of this cooperative through its direct marketing channel to end users

b. Using a personal loan at the beginning and after using the membership fee

c. Creating very informative marketing tools regarding the advantages of the products produced by the members of the cooperative

d. Providing visiting facilities for end users if they want to see plantations belonging to cooperative members

e. Provide product samples (if requested)

\section{Results and Discussion}

Cooperative is an institution formed with the aim of providing welfare or improving the economic and social quality of the community, here it can be interpreted that cooperatives have an important role in the social and economic development of the community. The administrative process that starts this activity is member registration, after the quota of members is sufficient then a cooperative is formed. Regarding the stages and procedures for establishing cooperatives as regulated in the Regulation of the Minister of Cooperatives and SMEs Number 9 of 2018 are as follows:

a. Cooperative Establishment Planning,

1. There must be a minimum of 20 members (primary cooperatives).

2. Determine the location of the cooperative. Have own capital (at least from principal savings, you can add mandatory savings, grants.

3. Determine the name of the cooperative (at least 3 words after the phrase cooperative). Make an initial business plan.

4. There are candidates for administrators and supervisors.

b. Submission of plans and consultations to the service (regional) or central (Ministry).

c. Cooperative Founding Meeting,

1. Attended by prospective founders, at least 20 people (for primary cooperatives).

2. Attended by extension officers from the service or ministry.

3. Can be attended by a notary.

4. The cooperative establishment meeting is chaired by the leadership and

5. Secretary is appointed by the founders.

6. The meeting elects the board of directors and supervisors and determines their term of service.

7. The cooperative establishment meeting discusses the draft articles of association. The results of the meeting are made in the minutes of the meeting and/or the Minutes of the Meeting.

8. Minutes of the meeting or minutes of the meeting shall be set forth in the draft Articles of Association of the Cooperative.

9. The notary shall record the agreement on the main points of discussion at the founding meeting.

10. The main points of the discussion are formulated in the Deed of Establishment of the Cooperative.

d. Cooperative Name Verification, 
1. The notary confirms the determination of the name of the cooperative in the Cooperative Legal Entity Service Administration System (Sisminbhkop).

2. Cooperatives that have obtained name approval are required to apply for a Deed of Establishment within 30 days at the latest.

e. Filing of Legalization of Cooperative Establishment Deed,

1. To obtain approval of the deed of establishment of the Cooperative, the founder or the proxies of the founders shall submit a written request for approval to the minister through Sisminbhkop.

2. A request for approval is submitted by attaching: 2 copies of the Cooperative's establishment deed, and one of them is sufficiently stamped; Minutes of the meeting of the establishment of the Cooperative, including the granting of power of attorney to apply for ratification, if any; proof of deposit of minimum capital equal to the principal savings; and initial plans for Cooperative business activities.

f. Verification of Application Documents,

1. Attachment to the application for Ratification of the Cooperative Establishment Deed submitted by the applicant is accompanied by the requirements and supporting documents (to fulfill the requirements for the establishment of a cooperative).

2. Documents submitted by the applicant to be examined and examined by the competent authority through the Sisminbhkop.

3. The official authorized to issue a receipt to the applicant, after the documents are declared complete and meet the requirements.

4. Document files and receipts are kept by the Notary.

g. Mechanisms at Sisminbhkop,

1. Application for the ratification of the Deed of Establishment of Cooperatives shall be made in writing by filling in the Form for the Deed of Establishment of Cooperatives as available on the Sisminbhkop.

2. An application for the approval of the Cooperative Establishment Deed is submitted by the applicant by scanning and uploading documents.

3. The Sisminbhkop administrator checks the form and documents from the applicant.

4. If the form is not in accordance with the provisions of the legislation, the authorized official shall notify the reason for the refusal to the applicant electronically. The refusal can be corrected or corrected by the applicant and then resubmitted through the Sisminbhkop.

h. Ratification of Cooperative Establishment,

1. The Minister issues a decision to ratify the Deed of Establishment of cooperatives within a maximum period of 7 days as of filling out the form for the deed of establishment and the uploaded documents are declared to have been fulfilled completely and correctly.

2. The Decree of the Minister shall be submitted to the Applicant electronically. The Notary may directly print the Decree of the Minister concerning the ratification of the Deed of Establishment of the Cooperative.

3. Decisions on the ratification of the Deed of Establishment of Cooperatives are compiled by the Ministry of Cooperatives and SMEs and recorded in the General Register of Cooperatives and can be made electronically.

4. The Ministry of Cooperatives and SMEs are required to submit a copy of the decision to ratify the Deed of Establishment of Cooperatives to the Office (province/district/city) at the location of the cooperative's domicile 


\section{Conclusion}

Starting to grow awareness of farmers about the importance of joining together in order to strengthen the economic potential in general. Because so far the results achieved for farmers are that the purchase price tends to be higher than selling to middlemen or dealers. Farmers feel safer selling to middlemen, it will be safer because all sales can be sold quickly even though there are traditional markets which are very close to the farmers' location. Thus, the formation of farmer groups and cooperatives can serve as a substitute for middlemen. So that the product can be sold by farmers at a more competitive price. In addition, cooperatives can also provide special savings and loan services for farmers which of course will be mutually beneficial for all parties, as well as develop a wider promotion and sales system.

\section{Recomendation}

It is hoped that this institution will become large with a variety of commodities that can be accommodated on a large scale. Then it is also hoped that the members and management of the cooperative can advance cooperatives, especially in food cooperatives to foreign countries.

It is recommended to integrate with village-related elements such as the Village Government, Youth Organizations, Mosque Family Council, PKK mothers. This is important to do so that the formation of farmer cooperatives can be accelerated.

\section{Acknowledgments}

The author would like to thank the Rector of Universitas Komputer Indonesia, Prof. Dr. Ir. H. Eddy Soeryanto Soegoto, M.T., the Dean of the Faculty of Economics and Business Assoc. Prof. Dr. Ely Suhayati, S.E., M.Si., Ak. CA, The Head of Marketing Management Department, Windi Novianti, S.E., M.M. In addition, I would also like to thank the farmers in Desa Cipanas in Cianjur Regency who were willing to cooperate in this activity.

\section{Reference}

Camelia Fanny Sitepu dan Hasyim. Perkembangan Ekonomi Koperasi Di Indonesia. Niagawan. Vol. 7 No. 2, Juli 2018

Dwipradyana, I. M.M., Mas, I. G. A. M. A., Pratiwi, A., dan Diatmika, I. G. N. D. (2020). Strategi Pengembangan Koperasi Di Era Digital Pada Koperasi Yang Ada Di Provinsi Bali. Majalah IImiah Universitas Tabanan, 17(2), 112-116

Gede Arwana. Manajemen koperasi menuju kewirausahaan koperasi. widya amerta jurnal manajemen fakultas ekonomi. Vol. 1. No. 1. Maret 2014

IEEE, "How to Cite References: IEEE Documentation Style,", 2019. [Online]. Available:http://https://ieeedataport.org/sites/default/files/analysis/27/IEEE\%20 Citation\%20Guidelines.pdf [Accessed: February. 5, 2019]

Manajemen Koperasi. Arief Subyantoro, Aryono Yacobus, dan Sudaryanto. 2015

Peraturan Menteri Koperasi dan Usaha Mikro Kecil Menengah No. 09 Tahun 2018 tentang Penyelenggaraan dan Pembinaan Perkoperasian

Rochmadi, I. (2001). Analisis Dampak Perdagangan Bebas Dan Global Pada Bergesernya Nilai Budaya, Prinsip Dan Tujuan Koperasi. Jurnal Ekonomika, 4(2), 45-51

Undang-Undang Republik Indonesia No. 25 Tahun 1992 Tentang Koperasi 